Jurnal Peternakan Integratif Vol.3 No.1;62-70

\title{
KECERNAAN BAHAN KERING DAN BAHAN ORGANIK RANSUM YANG MENGANDUNG PELEPAH DAUN KELAPA SAWIT DENGAN PERLAKUAN FISIK, KIMIA, BIOLOGI DAN KOMBINASINYA PADA DOMBA
}

\section{(Digestibility Dry Matter and Organic Matter of Oil Palm Frond with Treated Physical, Chemical, Biological and There Combination on Sheep)}

\author{
Thomas Jekin Vindonta Surbakti ${ }^{1}$, Ma'ruf Tafsin² dan Armyn Hakim Daulay ${ }^{2}$ \\ 1: Mahasiswa Program Studi Peternakan Fakultas Pertanian Universitas Sumatera Utara \\ 2: Staf Pengajar Program Studi Peternakan Fakultas Pertanian Universitas Sumatera Utara
}

\begin{abstract}
The research was conducted at Livestock Biology Laboratory at Department of Animal Husbandry, Agriculture Faculty,University of Sumatra Utara. The research started from June to August 2013 using completely randomize designs, with four treatments and four replications. Sixteen growing local sheep with initial body weight $10 \pm 1,16 \mathrm{~kg}$ were used in this experiment. The experiment were: P0 (concentrate + oil palm frond be treated a physical); P1 (concentrate + oil palm frond be treated a biological); P2 (concentrate + oil palm frond be treated a chemical); and P3 (concentrate + oil palm frond be treated a combination). The variables were measured consist of dry matter intake and organic matter intake, dry matter digestibility and organic matter digestibility. The result of this research showed that digestibility of oil palm frond treated by, chemical, biological and combination on sheep were significantly higher on dry matter intake, organic matter intake, dry matter digestibility than physical treatment. However, the treatmens were not significantly different $(P>0.05)$ on organic matter digestibility. It is concluded that treatment of biological, chemical and combination (biology + chemical) had positive effect on dry matter digestibility on sheep but not on phisical treatment. However analisis for organic matter digestibility doesn't showed giving influence for every treatment.
\end{abstract}

Keywords: Oil palm frond, physical, chemical, biological, digestibility, sheep.

\begin{abstract}
ABSTRAK
Penelitian ini dilaksanakan di Laboratorium Biologi Ternak, Departemen Peternakan, Fakultas Pertanian, Universitas Sumatera Utara, Medan, dilaksanakan pada bulan Juni - Agustus 2013 menggunakan rancangan acak lengkap (RAL) dengan empat perlakuan dan empat ulangan, menggunakan domba lokal jantan sebanyak 16 ekor dengan rataan bobot badan awal $10 \pm 1,16 \mathrm{~kg}$. Perlakuan yang diuji meliputi: P0 (konsentrat + pelepah kelapa sawit diolah secara fisik); P1 (konsentrat + pelepah kelapa sawit diolah secara biologi); P2 (konsentrat + pelepah kelapa sawit diolah secara kimia); dan P3 (konsentrat + pelepah kelapa sawit diolah secara kombinasi). Parameter yang diamati adalah konsumsi bahan kering, bahan organik, kecernaan bahan kering dan kecernaan bahan organik. Hasil penelitian menunjukkan bahwa ransum yang mengandung pelepah daun kelapa sawit diolah secara, kimia, biologis dan kombinasinya pada domba secara siginifikan lebih tinggi terhadap konsumsi bahan kering, konsumsi bahan organik, kecernaan bahan kering tetapi tidak berbeda nyata $(\mathrm{P}>0.05)$ terhadap kecernaan bahan organik. Kesimpulan hasil penelitian ini adalah kecernaan bahan kering ransum yang mengandung pelepah daun kelapa sawit memberikan pengaruh yang positif pada perlakuan biologi, kimia dan kombinasinya (biologi + kimia) tetapi tidak pada perlakuan fisik. Pada kecernaan bahan organik tidak memberikan pengaruh pada tiap-tiap perlakuan.
\end{abstract}

Kata Kunci: Pelepah daun kelapa sawit, fisik, kimia, biologis, kecernaan, domba. 


\section{PENDAHULUAN}

Domba merupakan salah satu ternak penghasil daging yang dapat memenuhi kebutuhan sumber protein asal hewani pada manusia. Untuk meningkatkan produksi daging domba pada masyarakat maka perlu perbaikan dalam manajemen pakan.

Kekurangan akan sumber pakan menjadi masalah yang besar pada ternak domba. Salah satu solusi untuk mengatasi kekurangan akan sumber pakan adalah dengan cara memanfaatkan limbah pertanian yang ada. Limbah pertanian yang dipilih untuk dijadikan sebagai bahan pakan untuk ternak tersebut harus disukai ternak, tidak beracun, tersedia dalam jumlah banyak, murah, tersedia sepanjang tahun dan tidak bersaing dengan manusia. Pelepah kelapa sawit dapat digunakan sebagai bahan pakan alternatif untuk ternak ruminansia khususnya ternak domba di Sumatera Utara.

Pelepah daun kelapa sawit merupakan salah satu limbah perkebunan kelapa sawit, dimana keberadaannya cukup tersedia melimpah sepanjang tahun di Indonesia khususnya Sumatera Utara. Luas lahan perkebunan kelapa sawit di Indonesia mencapai 7,1 juta Ha tahun 2008 (Direktoral Jenderal Perkebunan, 2009). Sumatera Utara sendiri pada tahun 2008 memiliki luas perkebunan kelapa sawit $948.800 \mathrm{Ha}$.

Pelepah dan daun kelapa sawit dapat diperoleh sepanjang tahun bersamaan panen tandan buah segar. Pelepah kelapa sawit dipanen 1 - 2 pelepah/panen/pohon. Setiap tahun dapat menghasilkan 22 - 26 pelepah/ pohon/ tahun dengan rataan berat pelepah daun sawit 4 - $6 \mathrm{~kg} /$ pelepah, bahkan produksi pelepah dapat mencapai 40 - 50 pelepah/pohon/tahun dengan berat sebesar 4,5 kg/pelepah. Hasil panen pelepah ini merupakan potensi yang cukup besar sebagai pakan ternak ruminansia. Pelepah kelapa sawit saat ini belum dimanfaatkan secara optimal merupakan salah satu bahan pakan pengganti hijauan (Kawamoto et al., 2002), disamping hasil ikutan lain dalam pengolahan buah kelapa sawit.

Hasil analisisi Laboratorium Ilmu Nutrisi Makanan Ternak Universitas Sumatera Utara menunjukkan bahwa pelepah dan daun kelapa sawit mengandung serat kasar 32,55\%, protein kasar 6,50\%, lemak 4,47\% dan TDN 56\%. Permasalahan yang dihadapi dalam penggunaan limbah perkebunan kelapa sawit seperti pelepah dan daun. Kelapa sawit adalah tingginya kandungan serat kasar dan rendahnya nilai protein sehingga kecernaannya menjadi rendah. Upaya yang dapat diupayakan mengatasi permasalahan tersebut dengan melakukan pengolahan pakan secara fisik, kimia, biologis dan kombinasinya.

Pelepah daun kelapa sawit tergolong bahan pakan yaitu kandungan protein kasarnya rendah sementara kandungan serat kasarnya tinggi. Untuk mengatasi permasalahan tersebut, 
dibutuhkan pengolahan yang tepat sebelum digunakan sebagai pakan ternak sehingga memberikan nilai tambah yakni menambah pakan dan mengurangi penggunaan hijauan lapangan yang semakin sulit diperoleh dilingkungan serta menambah nilai bagi petani. Hal ini dapat mengurangi dampak pencemaran lingkungan dan dapat menambah persediaan bahan makanan ternak.

Dari uraian diatas penulis tertarik untuk mengetahui penggunaan pelepah daun kelapa sawit dengan berbagai perlakuan (fisik, kimia, biologis dan kombinasi) terhadap kecernaan bahan kering dan bahan organik.

\section{BAHAN DAN METODE PENELITIAN}

\section{Tempat dan Waktu Penelitian}

Penelitian dilaksanakan di Laboratorium Biologi Ternak jln Prof. Dr. A Sofyan no 3. Program Studi Peternakan Fakultas Pertanian Universitas Sumatera Utara Medan. Penelitian berlangsung selama 2 bulan dimulai bulan juni 2013 sampai agustus 2013.

\section{Bahan dan Alat Penelitian}

Adapun domba yang digunakan adalah domba local jantan lepas sapih sebanyak 16 ekor dengan bobot bada awal $10 \pm 1.16 \mathrm{~kg}$. Pakan konsentrat yang terdiri dari tepung jagung, bungkil inti sawit, dedak padi, molasses, urea, mineral mix dan garam. Pelepah kelapa sawit fermentasi sebagai pengganti pakan rumput ternak, Aspergillus niger sebagai fermentor pelepah kelapa sawit, obat-obatan seperti obat cacing (Nemasol), anti bloat untuk obat gembung, Rhodallon untuk desinfektan dan vitamin. Air minum diberikan secara adlibitium.

Kandang terdiri atas kandang individu 16 unit dengan ukuran 1 x $1 \mathrm{~m} 2$ beserta perlengkapannya, ember sebanyak 16 buah tempat pakan dan 16 buah tempat minum, timbangan untuk menimbang bobot hidup berkapasitas $150 \mathrm{~kg}$ dengan kepekaan $50 \mathrm{~g}$, timbangan berkapasitas $2 \mathrm{~kg}$ dengan kepekaan $10 \mathrm{~g}$ untuk menimbang pakan, pampers untuk menampung urine domba, terpal plastik untuk menjemur bahan pakan, alat penerangan, goni plastik, alat tulis.

\section{Metode Penelitian}

Metode penelitian yang digunakan adalah Rancangan Acak Lengkap (RAL) non faktorial dengan 4 perlakuan dan 4 ulangan. Adapun perlakuan tersebut adalah:

P0: Pelepah daun kelapa sawit diolah secara fisik (chooper)

P1: Pelepah daun kelapa sawit diolah secara biologis (fermentasi dengan Aspergillus niger) 
P2: Pelepah daun kelapa sawit diolah secara kimia (amoniasi)

P3: Pelepah daun kelapa sawit diolah secara kombinasi

Keterangan: Setiap perlakuan ditambah konsentrat sebanyak $1 \%$

Metode linier rancangan percobaan yang digunakan menurut Mattjik dan Sumertajaya (2002) adalah sebagai berikut:

$$
\mathbf{Y}_{\mathrm{ij}}=\boldsymbol{\mu}+\mathbf{T}_{\mathrm{i}}+\mathbf{i j}
$$

Keterangan:

I $\quad=1,2 \ldots$. Perlakuan.

J $\quad=1,2 \ldots \ldots$ Ulangan.

$\mathrm{Y}_{\mathrm{ij}} \quad=$ Respon atau nilai pengamatan dari perlakuan ke-I dan ulangan ke-j.

$\mu \quad=$ Nilai tengah umum.

$\mathrm{T}_{\mathrm{i}} \quad=$ Pengaruh perlakuan ke-i.

ij = Pengaruh galat percobaan dari perlakuan ke-I dan ulangan ke-j.

\section{Analisis Data}

Untuk mengetahui pengaruh perlakuan terhadap peubah yang diukur, data yang diperoleh dianalisis dengan sidik ragam dan dilanjutkan dengan uji Beda Nyata Terkecil (BNT) (Steel danTorrie, 1993).

\section{Parameter Penelitian}

\section{a. Konsumsi (bahan kering dan bahan organik)}

Konsumsi bahan kering dan bahan organik diukur dengan mengalikan konsumsi ransum dengan kandungan bahan kering dan bahan organik yang diperoleh dari data analisis di laboratorium. Periode pengukuran dilakukan selama satu minggu.

\section{b. Kecernaan Bahan Kering (KcBK)}

Kecernaan bahan kering dapat diukur dengan menghitung berdasarkan rumus: $K c B k=\underline{(B K \text { Konsumsi }-B K \text { darifeses })} \times 100 \%$

\section{BK konsumsi}

Konsumsi dan pengeluaran feses (BK) diperoleh dalam jangka waktu pengukuran selama periode koleksiya itu satu minggu.

\section{c. Kecernaan Bahan Organik (KcBO)}

Kecernaan bahan organik dapat diukur dengan menghitung berdasarkan 
Rumus : KcBO $=\underline{(B O \text { Konsumsi }-B O \text { darifeses })} \times 100 \%$

BO Konsumsi

Konsumsi dan pengeluaran feses (BO) diperoleh dalam jangka waktu pengukuran selama periode koleksiya itu selama satu minggu (Hardjosubroto dan Astuti, 1993).

Tabel 1. Susunan komposisi ransum percobaan

\begin{tabular}{lcccc}
\hline \multirow{2}{*}{ Kandungan nutrisi bahan } & \multicolumn{4}{c}{ Komposisi bahan pakan } \\
\cline { 2 - 5 } & P0 & P1 & P2 & P3 \\
\hline Pelepah daun kelapa sawit (fisik) & 50 & 0 & 0 & 0 \\
Pelepah daun kelapa sawit (biologi) & 0 & 50 & 0 & 0 \\
Pelepah daun kelapa sawit (amoniasi) & 0 & 0 & 50 & 0 \\
Pelepah daun kelapa sawit & & & & \\
(kombinasi) & 0 & 0 & 0 & 50 \\
Tepung jagung & 7.5 & 7.5 & 7.5 & 7.5 \\
Bungkil inti sawit & 20.5 & 20.5 & 20.5 & 20.5 \\
Dedak padi & 16 & 16 & 16 & 16 \\
Molasses & 4 & 4 & 4 & 4 \\
Garam & 0.5 & 0.5 & 0.5 & 0.5 \\
Mineral & 0.5 & 0.5 & 0.5 & 0.5 \\
Urea & 1 & 1 & 1 & 1 \\
\hline \multicolumn{1}{c}{ Total } & 100 & 100 & 100 & 100 \\
\hline & & & & \\
\hline Protein Kasar (PK) & 11.35 & 14.99 & 12.98 & 15.12 \\
Serat Kasar (SK) & 23.21 & 20.54 & 20.83 & 19.95 \\
Lemak Kasar (LK) & 4.37 & 4.56 & 4.29 & 4.28 \\
Total Digestible Nutrient (TDN) & 54.46 & 55.37 & 53.73 & 54.91 \\
\hline
\end{tabular}

\section{HASIL DAN PEMBAHASAN}

Rekapitulasi hasil penelitian kecernaan bahan kering dan bahan organik pelepah daun kelapa sawit dengan perlakuan fisik, biologis, kimia dan kombinasinya pada domba dapat dilihat pada Tabel 2 .

\section{Konsumsi Bahan Kering (BK)}

Tabel 2 menunjukkan bahwa konsumsi bahan kering dengan rataan tertinggi pada perlakuan P1 yaitu sebesar 393,42 \pm 10.92 g/ekor/hari dan rataan konsumsi bahan kering terendah memberikan pengaruh yang sama pada perlakuan P0 sebesar $345.18 \pm 21.81$ 
g/ekor/hari , P2 sebesar $219.63 \pm 21.26$ g/ekor/hari, P3 sebesar $299.18 \pm 51.47$ g/ekor/hari. Berdasarkan hasil analisis ragam diketahui bahwa pemberian pakan dengan menggunakan pelepah daun kelapa sawit dengan perlakuan fisik, biologis, kimia dan kombinasinya pada domba memberikan pengaruh yang sangat nyata $(\mathrm{P}<0.01)$ terhadap konsumsi bahan kering (BK).

Tabel 2. Rekapitulasi hasil penelitian (g/ekor/hari).

\begin{tabular}{lcccr}
\hline \multirow{2}{*}{ Perlakuan } & \multicolumn{4}{c}{ Parameter Penelitian } \\
\cline { 2 - 5 } & Konsumsi BK & Konsumsi BO & KCBK & \multicolumn{1}{c}{ KCBO } \\
\hline P0 & $345.18^{\mathrm{A}} \pm 21.81$ & $265.82^{\mathrm{A}} \pm 16.80$ & $62.43^{\mathrm{A}} \pm 3.13$ & $63.94^{\mathrm{tn}} \pm 4.67$ \\
P1 & $393.42^{\mathrm{B}} \pm 10.92$ & $297.07^{\mathrm{B}} \pm 8.24$ & $70.23^{\mathrm{B}} \pm 3.07$ & $70.27^{\mathrm{tn}} \pm 3.55$ \\
P2 & $319.63^{\mathrm{A}} \pm 21.26$ & $244.55^{\mathrm{A}} \pm 16.27$ & $68.01^{\mathrm{A}} \pm 1.95$ & $67.94^{\text {tn }} \pm 1.89$ \\
P3 & $299.18^{\mathrm{A}} \pm 51.47$ & $221.42^{\mathrm{A}} \pm 38.09$ & $67.97^{\mathrm{A}} \pm 2.21$ & $67.70^{\text {tn }} \pm 2.14$
\end{tabular}

Keterangan : A, B superskrip yang berbeda pada kolom yang sama menunjukan perbedaan yang sangat nyata $(\mathrm{P}<0,01)$ tn $=$ tidak berbeda nyata $(\mathrm{P}>0.05)$

Hasil uji lanjut dengan BNT menunjukkan bahwa konsumsi bahan kering pada perlakuan P1 lebih tinggi disebabkan karena memberikan aroma yang baik pada pakan sehingga dapat meningkatkan palatabilitas terhadap pakan tersebut. Hal ini sesuai dengan pernyataan Parakkasi (1995) yang menyatakan bahwa palatabilitas pakan merupakan salah satu faktor yang mempengaruhi jumlah konsumsi pakan. Sedangkan pada perlakuan P0: P2: dan P3 memberikan potensi yang sama pada pada ketiga perlakuan tersebut dan berbeda nyata pada perlakuan P1.

Hasil penelitian menunjukkan bahwa pada perlakuan P0, P1, P2 dan P3 menunjukkan hasil yang berbeda sangat nyata pada perlakuan P1 karena perlakuan P1 dilakukan dengan pengolahan secara biologis oleh mikroba Aspergillus niger sehingga peningkatkan palatabilitas pakan pada ternak. Hal ini sesuai dengan pernyataan Panto (2011) yang menyatakan bahwa kandungan serat kasar dari pelepah sawit yang telah difermentasi dengan Aspergillus niger menjadi lebih rendah sehingga kualitas konsentrat menjadi lebih baik.

\section{Konsumsi Bahan Organik (BO)}

Data konsumsi bahan organik pada Tabel 2. memperlihatkan konsumsi bahan organik dengan rataan tertinggi pada perlakuan P1 yaitu sebesar $297.07 \pm 8.24$ g/ekor/hari dan rataan konsumsi bahan organik terendah memberikan pengaruh yang sama pada perlakuan P0 
sebesar $265.82 \pm 16.80 \mathrm{~g} / \mathrm{ekor} / \mathrm{hari}, \mathrm{P} 2$ sebesar $244.55 \pm 21.26 \mathrm{~g} / \mathrm{ekor} / \mathrm{hari}$ pada perlakuan P3 sebesar $221.42 \pm 38.09$ g/ekor/hari. Berdasarkan hasil analisis ragam diketahui bahwa pemberian pakan dengan menggunakan pelepah daun kelapa sawit dengan perlakuan fisik, biologis, kimia dan kombinasinya pada domba memberikan pengaruh yang sangat nyata $(\mathrm{P}<0.01)$ terhadap konsumsi bahan organik $(\mathrm{BO})$.

Hasil uji lanjut dengan BNT menunjukkan bahwa konsumsi bahan organik pada perlakuan P1 lebih tinggi dibandingkan dengan perlakuan yang lainnya. Hasil konsumsi bahan organik sejalan dengan konsumsi bahan kering yaitu teringgi pada perlakuan P1. Sedangkan pada perlakuan P0; P2; dan P3 mempunyai notasi yang sama yang artinya memberikan potensi yang sama pada perlakuan tersebut.

Hasil konsumsi bahan organik sejalan dengan hasil konsumsi bahan kering sesuai dengan pernyataan Jusuf (2010) yang menyatakan bahwa konsumsi pakan bahan organik ini sejalan dengan konsumsi bahan kering. Sutardi (1979) juga menyatakan bahwa bahan organik berkaitan erat dengan bahan kering karena bahan organik berkaitan erat dengan bahan kering. Selanjutnya Tillman et al., (1991) menyatakan bahwa sebagian besar bahan organik merupakan komponen bahan kering. Didukung juga oleh Kamal (1994), konsumsi bahan kering memiliki bahan terdiri dari bahan organik dan abu sehingga besarnya konsumsi besarnya konsumsi bahan organik berbanding lurus dengan besarnya konsumsi bahan kering.

\section{Kecernaan Bahan Kering (KcBK)}

Kecernaan suatu bahan makanan merupakan selisih dari bahan makanan yang tidak diekskresikan melalui feses atau bagian yang diserap oleh saluran pencernaan dan dimanfaatkan oleh mikroba dalam alat pencernaan. Untuk melihat pengaruh dari uji pakan Pelepah Daun Kelapa Sawit dengan Perlakuan Fisik, Biologis, Kimia dan Kombinasinya terhadap kecernaan bahan kering pada domba lokal dapat dilihat dari rataan kecernaan bahan kering (BK) yang tertera pada Tabel 2.

Data kecernaan bahan kering pada Tabel 2, memperlihatkan kecernaan bahan kering dengan rataan tertinggi pada perlakuan P1 yaitu sebesar $70.23 \pm 3.07$ g/ekor/hari dan rataan kecernaan bahan kering terendah memberikan pengaruh yang sama pada perlakuan P0 sebesar $62.43 \pm 3.13$ g/ekor/hari, P2 sebesar $68.01 \pm 1.95$ g/ekor/hari, P3 sebesar $67.97 \pm$ $2.21 \mathrm{~g} / \mathrm{ekor} / \mathrm{hari}$. Berdasarkan hasil analisis ragam diketahui bahwa pemberian pakan dengan menggunakan pelepah daun kelapa sawit dengan perlakuan fisik, biologis, kimia dan 
kombinasinya pada domba memberikan pengaruh yang sangat nyata $(\mathrm{P}<0.01)$ terhadap kecernaan bahan kering (KcBK).

Hasil uji lanjut dengan BNT menunjukkan bahwa P0, P2 dan P3 memberikan

pengaruh yang sama terhadap KCBK, tetapi sangat nyata dibandingkan dengan P1, ini disebabkan tingkat kecernaan bahan kering sejalan dengan konsumsi bahan kering. Aroma yang baik pada perlakuan P1 menyebabkan palatabilitas yang tinggi sehingga konsumsi bahan kering yang tinggi diikuti dengan kecernaan bahan kering yang tinggi. Sesuai dengan pernyataan Tomaszewska, et al., (1993) yang menyatakan bahwa tingkat konsumsi sangat dipengaruhi oleh kofisien cerna, kualitas pakan, fermentasi dalam rumen, serta status fisiologi ternak. Kualitas pakan ditentukan oleh tingkat kecernaan zat-zat makanan yang terkandung pada pakan tersebut. Zat makanan tersebut tidak seluruhnya tersedia untuk tubuh ternak, sebagian akan dikeluarkan melalui feses. Kecernaan pakan pada ternak ruminansia sangat erat hubungannya dengan jumlah mikroba rumen.

\section{Kecernaan Bahan Organik (KcBO)}

Kecernaan bahan organik menunjukan derajat cerna pakan pada alat-alat pencernaan serta seberapa besar sumbangan suatu pakan bagi ternak. Untuk melihat pengaruh dari uji pakan Pelepah Daun Kelapa Sawit dengan Perlakuan Fisik, Biologis, Kimia dan Kombinasinya terhadap kecernaan bahan kering pada domba dapat dilihat dari rataan kecernaan bahan organik (BO) yang tertera pada Tabel 2.

Data kecernaan bahan organik pada Tabel 2 memperlihatkan bahwa tingkat kecernaan bahan organik dengan rataan tertinggi pada perlakuan P1 yaitu sebesar $70.27 \pm 3.55$ g/ekor/hari dan rataan kecernaan bahan organik terendah terendah pada perlakuan P0 sebesar $63.94 \pm 4.67 \mathrm{~g} / \mathrm{ekor} / \mathrm{hari}$. Berdasarkan hasil analisi ragam diketahui bahwa pemberian pakan dengan menggunakan pelepah daun kelapa sawit dengan perlakuan fisik, biologis, kimia dan kombinasinya pada domba memberikan pengaruh yang tidak berbeda nyata $(\mathrm{P}>0.05)$ terhadap kecernaan bahan organik (KcBO) pada domba jantan. Hal ini berhubungan dengan komposisi kimia dari pakan tiap perlakuan yang dapat berpengaruh terhadap daya cerna pakan, sebab kemampuan kecernaan suatu pakan bergantung pada kualitas zat makanan yang terdapat didalam pakan sehingga berpengaruh tehadap pertumbuhan mikroorganisme. Hal ini sesuai dengan pernyataan Sandri (2009) yang menyatakan bahwa komposisi kimia dari pakan perlakuan yang dapat mempengaruhi daya cerna pakan. Daya cerna suatu pakan tergantung pada keserasian dari zat-zat makanan yang terkandung didalamnya. 


\section{KESIMPULAN}

Kecernaan bahan kering ransum yang mengandung pelepah daun kelapa sawit memberikan pengaruh yang positif pada perlakuan biologi, kimia dan kombinasinya (biologi + kimia) tetapi tidak pada perlakuan fisik. Pada kecernaan bahan organik tidak memberikan pengaruh pada tiap-tiap perlakuan.

\section{DAFTAR PUSTAKA}

Davendra, C. dan Burns M., 1994. Produksi Kambing di Daerah Tropis. Institut Teknologi Bandung dan Universitas Udayana Bali.

Direktorat Jenderal Perkebunan. 2009. Statistik Perkebunan Indonesia 2008-2010. Sekretariat Direktorat Jenderal Perkebunan. Jakarta. 57 hal.

Harahap, Y. A., 2011. Pelepah dan Daun Kelapa Sawit Terfermentasi A. niger Dalam Konsentrat Terhadap Kecernaan Bahan Kering dan Bahan Organik Ransum Pada Sapi Bali (BosSondaicus).Skripsi. Universitas Sumatera Utara. Medan.

Hardjosubroto, W dan Astuti. J. M. 1993. Buku Pintar Peternakan. Gramedia Widiasarana Indonesia. Jakarta.

Kartadisastra, H.R., 1997. Penyediaan dan Pengelolaan Pakan Ternak Ruminansia. Kanisius. Yogyakarta.

Kawamoto, H; M. Wan Azhari; N.I. Mohd.Shukur; M.S. Ali; J. Ismail and S. Oshiho, 2002. Palatability digestibility and volumary intake ofprocessed oil fronds in cattle.Dalam Prosiding Lokakarya Nasional.Bengkulu.

Laboratorium Nutrisi dan Pakan Ternak. 2005. Program Studi Peternakan FP USU, Medan.

Mattjik, A. A. dan I. M. Sumertajaya. 2002. Perancangan dan Percobaan dengan Aplikasi SAS dan Minitab. Cetakan ke-2. IPB Press, Bogor.

N.R.C, 1985 .Nutrien Requirements Of Sheep, National Academy of Sceince, Washinton DC, USA.

Parakkasi, A., 1995. Ilmu Makanan dan Ternak Ruminant. UI Press, Jakarta.

Sagala, J. A., 2010. Kecernaan Buah Markisah (PasifloraOdulis) Difermentasi Phanerochae techrysosporium Pada Domba Lokal Fase Pertumbuhan. Skripsi. Universitas Sumatera Utara. Medan.

Sastrawan, S., 2009. Pemanfaatan Pelepah Sawit dan Hasil Ikutan Industri Kelapa Sawit Terhadap Kecernaan Bahan Kering dan Bahan Organik Pada Sapi Peranakan Siemental. Skripsi. Universitas Sumatera Utara. Medan. 
Sutardi, T., 1979. Ketahanan Protein Bahan Makanan terhadap Degradasi Mikroba Rumen dan Manfaatnya bagi Peningakatan Produktivitas Ternak. Prosiding Seminar Penelitian dan Penunjang Peternakan. LPP Institut Pertanian Bogor, Bogor.

Tillman, A.D, H. Hartadi, S. Reksohadiprodjo, S. Prawirokusumodan S. Lebdosoekojo., 1991. Ilmu MakananTernak Dasar. Gadjah Mada University Press, Yogyakarta.

Tomaszewska, M. W., I. M. Mastika., A. Djajanegara., S. Gardiner dan T. R. Wiradarya., 1993. Produksi Kambing dan Domba di Indonesia.Sebelas Maret, Surabaya. 